\title{
CD79A Gene Mutation
}

National Cancer Institute

\section{Source}

National Cancer Institute. CD79A Gene Mutation. NCI Thesaurus. Code C150433.

A change in the nucleotide sequence of the CD79A gene. 